\title{
EVALUATION OF THE DISPENSING RATE OF ISONIAZID USED IN THE PREVENTIVE TREATMENT OF TUBERCULOSIS IN A SERVICE SPECIALIZED IN HIV / AIDS
}

\section{ORIGINAL ARTICLE}

SANTANA, Claudinei Alves [1], GUTIERREZ, Eliana Battaggia ${ }^{[2]}$

SANTANA, Claudinei Alves. GUTIERREZ, Eliana Battaggia. Evaluation of the Dispensing Rate of Isoniazid Used in the Preventive Treatment of Tuberculosis in a Service Specialized in HIV / AIDS. Revista Científica Multidisciplinar Núcleo do Conhecimento. Year 06, Ed. 04, Vol. 03, pp. 05-21. April.

ISSN:

2448-0959,

Access

link: https://www.nucleodoconhecimento.com.br/health/isoniazid-used, DOI: 10.32749/nucleodoconhecimento.com.br/health/isoniazid-used

\section{ABSTRACT}

Introduction: Acquired immunodeficiency syndrome caused by the human immunodeficiency virus was one of the main epidemics of infectious diseases of the 20th century. Tuberculosis is a chronic, infectious and contagious disease caused by Mycobacterium tuberculosis. Both diseases interact becoming a major public health problem. Preventive treatment with isoniazid has an option for nonmanifestation of tuberculosis. Treatment adhering is essential for successful prevention. Objective: To evaluate the rate of compliance with preventive treatment with isoniazid, measured through the dispensation of the drug in the pharmacy and the factors associated between subjects with HIV/AIDS and Latent infection by Mycobacterium tuberculousis followed in specialized service in the care of HIV/AIDS patients. Methodology: Retrospective and prospective, descriptive and analytical study with adult patients with HIV/AIDS in follow-up, Extension Service for the Care of HIV/AIDS Patients of the Division of Infectious and Parasitic Diseases of the Hospital das Clínicas of the Faculty of Medicine of the University of São Paulo, using the Hospital Information and Management 
System (SIGH) implemented in the Outpatient Clinics and Pharmacy Service, and performing the analysis of association between the variables of interest and outcome through the student's t-test with $95 \% \mathrm{Cl}$, being considered with statistical significance $p \leq 5 \%$. Results: We included 161 subjects who participated in the study being $78.9 \%$ male, $67.7 \%$ under 50 years of age, $87.0 \%$ with more than 5 years of HIV infection, and complications during preventive treatment were present in $12.4 \%$ (20). The rate of adhering to preventive treatment with isoniazid in medical records and electronic prescription was $96 \%$ and $83 \%$, respectively, both being higher than $80 \%$ according to the recommendation of the World Health Organization and there was no association between the variables of interest and outcome. Conclusion: The high rate can be partially justified by practices adopted in medical and pharmaceutical care such as scheduling drug dispensing dates, unification for dispensing of different medications on the same date, information in the pharmacy about factors that increase the effectiveness of treatment. The adequate care and care provided was ultimately the great responsible for the results achieved.

Keywords: adherence to the ICC, electronic prescription, pharmacy service, tuberculosis, HIV / AIDS.

\section{INTRODUCTION}

Acquired immunodeficiency syndrome (AIDS), caused by the human immunodeficiency virus (HIV) was one of the main epidemics of infectious diseases of the twentieth century (BIGGAR, 1988; DE COOK et al, 2011). At the end of 2019 it was estimated that about 38 million people lived with HIV worldwide. (UNAIDS, 2020). In Brazil, from 1980 to June 2020, 1,011,617 cases of AIDS were reported in the country. (BRASIL, 2020).

Tuberculosis (TB) is a chronic, infectious and contagious disease caused by Mycobacterium tuberculosis (Mtb) (VERONESI, 2005). In 2018, about 10 million people developed tuberculosis, approximately $9 \%$ were living with HIV. 
(UNAIDS, 2020). TB is the second leading cause of death from infectious disease worldwide with 1.5 million deaths in 2018. (UNAIDS, 2020).

In Brazil, in 2019, 73,864 new cases of TB were diagnosed, which corresponded to an incidence coefficient of 35.0 cases/100,000 inhabitants. (BRASIL, 2020). HIV infection is one of the main risk factors for the development of TB (EL-SADR et al, 2008; STERLING et al, 2010). TB and HIV comorbidity brings special problems for the diagnosis of $\mathrm{TB}$, for the treatment of both diseases and consumes a large portion of health resources in developing countries (FÄTKENHEUER et al, 1999). TB is among the main causes of death among individuals with AIDS in these regions (BLANC et al, 2007).

The treatment of co-infected patients requires the use of tuberculostatic and antiretroviral drugs used concomitantly, and brings as challenges to patients the high number of pills, adherence, the possibility of drug interactions with overlapping toxic effects and inflammatory immune reconstitution syndrome (PADMAPRIYADARSINI et al, 2011).

One of the measures for the prevention of TB, in individuals infected with Mtb and with an increased risk of progressing to disease, is the preventive treatment with isoniazid (TPI) of Latent Mtb Infection (ILMtb) (CONDE et al, 2009; LEUNG et al , 2010; HORSBURGH; RUBIN, 2011; DUARTE et al, 2007). ILMTb is the presence of Mtb in a non-active phase, without producing clinical symptoms. It is estimated that up to a third of the world population is latently infected with Mtb (AKOLO et al, 2010). TPI can reduce the risk in people living with HIV / AIDS (PLWHA) by 33 to $67 \%$ for up to 48 months. The World Health Organization and the Ministry of Health, in order to reduce the risk of TB in PVHA, recommend administration of isoniazid (INH), at a dose of 5 to $10 \mathrm{mg} / \mathrm{kg} /$ day of weight up to $300 \mathrm{mg}$ for 6 months (540 tablets ) consecutive for the treatment of PLWHA with Tuberculin Test $>5 \mathrm{~mm}$, as long as active TB, current or previous, has been excluded (CONDE et al, 2009). It is important to highlight the risk of asymptomatic elevation of liver enzymes such as AST (aspartate aminotransferase), ALT (alanine aminotransferase) and GGT (gamma-glutamyltransferase) after starting treatment with INH. (CHURCHYARD et al, 2007; COHN, 2000). 
The concept of adhering varies among the authors. It can be defined as being how much the patient follows the guidelines of a health agent, with whom he agreed, and is considered as adherent to the ICC the patient who ingests at least $80 \%$ of the prescribed doses (WHO, 2003).

The evaluation of drug therapy adhering can be done directly and indirectly, with biochemical, objective, subjective and clinical methods, which are the most used worldwide (GORENOI et al, 2007).

One of the methods of assessing adherence to therapy may be through the dispensing of medication in the pharmacy, and for that purpose, the availability of systems that accurately record dispensing to patients is necessary (OIGMAN, 2003).

The Pharmacy Service is an integral part of the assistance in specialized HIV/AIDS Care Services according to the World Health Organization (WHO, 2008). It is also of great importance the clinical pharmacist's role in infectious diseases and pharmacy team in the assistance to PLWHA (VAN MIL et al, 2006).

\section{OBJECTIVE}

The main objective of this study was to evaluate the rate of ICC membership, measured by the amount of pills dispensed with isoniazid, correlated with the amount prescribed in medical records and the amount prescribed in the electronic prescription and the factors associated between subjects with HIV/AIDS and ILMtb in specialized service in the care of HIV/AIDS patients.

\section{METHODOLOGY}

\section{STUDY DESIGN}

Retrospective and prospective, descriptive and analytical study with adult HIV / AIDS patients undergoing follow-up at the HIV / AIDS Service Extension Service, Infectious and Parasitic Diseases Division, Hospital das Clínicas, University of 
São Paulo Medical School. (SEAP HIV / Aids), an outpatient clinic specialized in HIV / AIDS, with a Hospital Information and Management System (SIGH) implanted in the Ambulatory to prepare electronic prescriptions and in the Pharmacy Service for dispensing medications. The research was approved by the Ethics Committee for Analysis of Research Projects of the Faculty of Medicine of the University of São Paulo under number 1068/08.

\section{SELECTION OF SUBJECTS}

Subjects who presented at least 1 prescription of INH at the SEAP HIV / AIDS Pharmacy Service in the period from 01/07/2008 to 06/30/2011 were included. Subjects with previous TB and at the time of the study, who did not follow up during the study period and who started the ICC before 07/01/2008, were excluded.

\section{DATA COLLECTION}

Data were obtained from medical records through a standardized form, for the entire period of follow-up of the subject in the service; data were obtained through management reports generated from computers located in the Pharmacy Service.

The INH dispensation rate in the Pharmacy Service, the outcome of this study, of $\mathrm{INH}$ was calculated as the percentage relationship between the number of pills dispensed by the pharmacy and the estimated number of pills prescribed, according to the record in the medical record of the start and end dates. end of TPI reported in the medical record and the number of pills prescribed electronically (QCP), was calculated through the interval in days between the date of the 1st INH prescription registered at SIGH and the end date multiplied by the number of pills / day. $(300 \mathrm{mg}=3 \mathrm{cp})$. 


\section{STATISTICAL ANALYSIS}

The statistical analysis was performed with the Program SPSS - Statistics, version 17.0. Descriptive analysis of the variables was performed with measures of central tendency (mean, median, standard deviation, minimum and maximum) and proportions, and the Student's t-test for the associations, with $95 \% \mathrm{Cl}$, being considered with statistical significance $p \leq 5 \%$.

\section{RESULTS}

\section{SAMPLE CHARACTERISTICS}

We initially selected 203 subjects who presented prescription of INH in the period from $01 / 07 / 2008$ to $30 / 06 / 2011$, and after applying the exclusion criteria, 161 subjects were included (Figure 1) 
Figure 1 - Subject inclusion algorithm

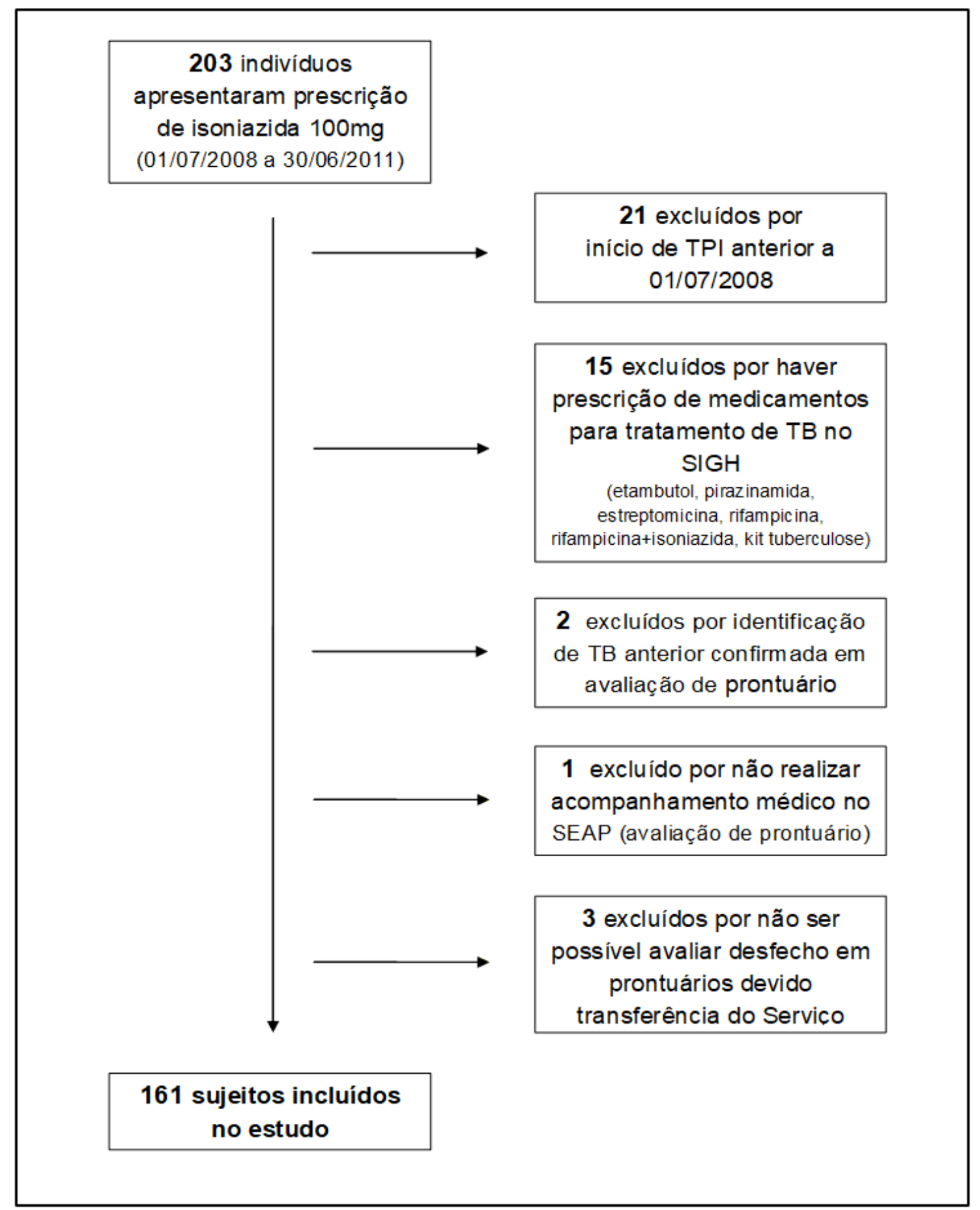

Source: Elaborated by the author 
Table 1- Characteristics of the subjects. SEAP HIV/AIDS, HC-FMUSP, São Paulo, 2008 to 2011

\begin{tabular}{|c|c|c|}
\hline Variável & $\mathbf{N}$ & $\%$ \\
\hline \multicolumn{3}{|l|}{ Sexo } \\
\hline $\mathrm{M}$ & 127 & 78,9 \\
\hline $\mathrm{F}$ & 34 & 21,1 \\
\hline \multicolumn{3}{|l|}{ Idade } \\
\hline$<50$ & 109 & 67,7 \\
\hline$\geq 50$ & 52 & 32,3 \\
\hline \multicolumn{3}{|c|}{ Doença Concomitante } \\
\hline Sim & 125 & 77,6 \\
\hline Não & 36 & 22,4 \\
\hline \multicolumn{3}{|c|}{ Uso de drogas lícitas ou ilicitas } \\
\hline Sim & 36 & 22,4 \\
\hline Não & 125 & 77,6 \\
\hline \multicolumn{3}{|l|}{ Anos Inf. HIV } \\
\hline$\leq 4$ anos & 21 & 13,0 \\
\hline$\geq 5$ anos & 140 & 87,0 \\
\hline \multicolumn{3}{|l|}{ Uso de TARV } \\
\hline Sim & 149 & 92,5 \\
\hline Não & 12 & 7,5 \\
\hline \multicolumn{3}{|c|}{ Núm. de comp. ARV } \\
\hline$\leq 3 \mathrm{cp}$ & 52 & 34,9 \\
\hline$\geq 4 \mathrm{cp}$ & 97 & 65,1 \\
\hline \multicolumn{3}{|c|}{ Acompanhamento Médico } \\
\hline assistente & 136 & 84,5 \\
\hline residente & 25 & 15,5 \\
\hline
\end{tabular}

Source: Elaborated by the author 
Figure 2- Algorithm of complications during the ICC

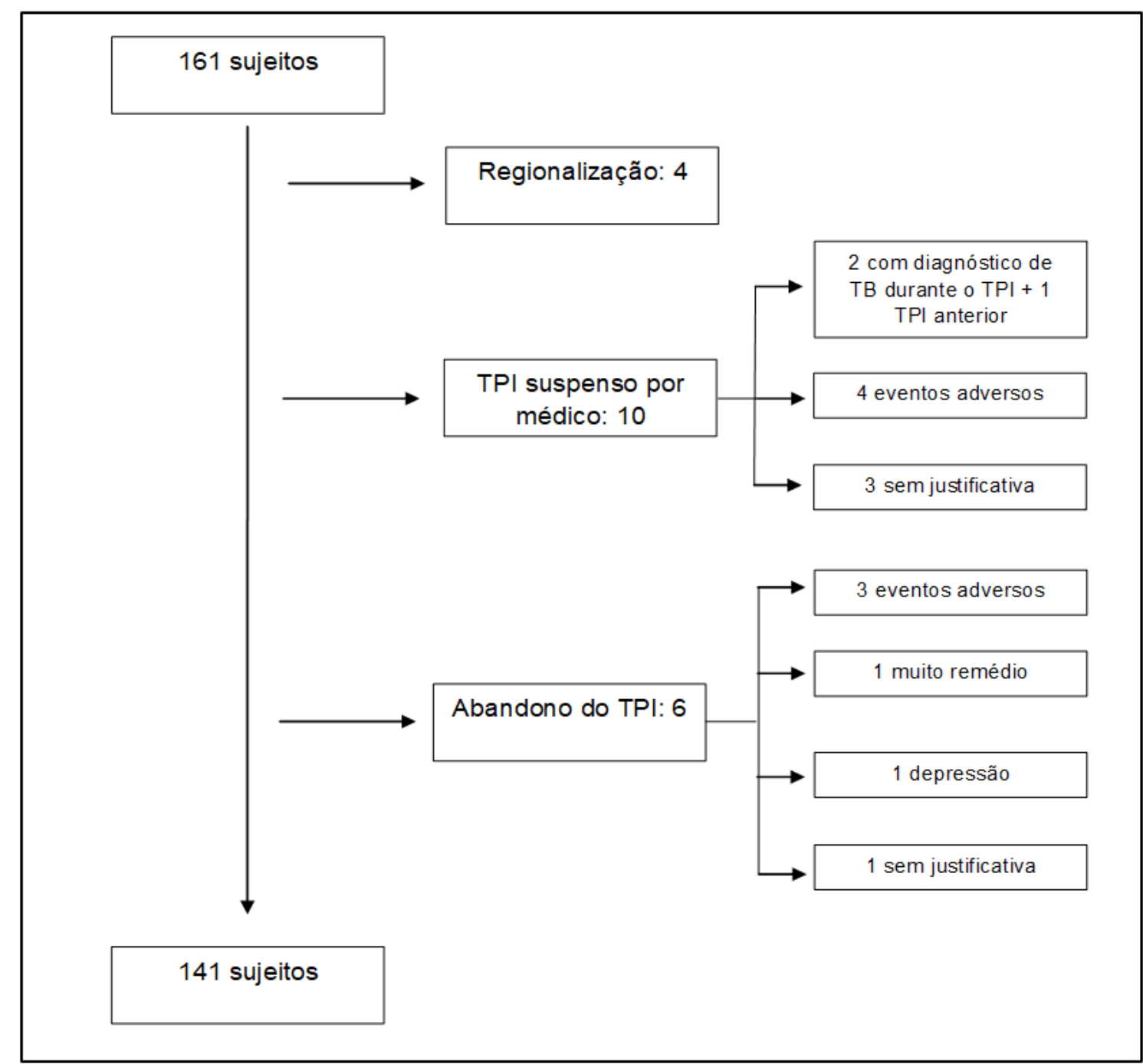

Source: Elaborated by the author

\section{EVALUATION OF ADESION DESCRIBED IN MEDICAL RECORDS}

The evaluation of ICC adhering was recorded in medical records for $13 \%$ (21) of the subjects, being considered good in $24 \%$ (5) of them. In the evaluation of adhering to subjects who used TARV, there was information in medical records for $53 \%$ (79) subjects, being considered good in $41 \%$ (32).

Graph 1. Evaluation of ICC adtois described in medical records. SEAP HIV/AIDS, HC-FMUSP, São Paulo - 2008 to 2011 


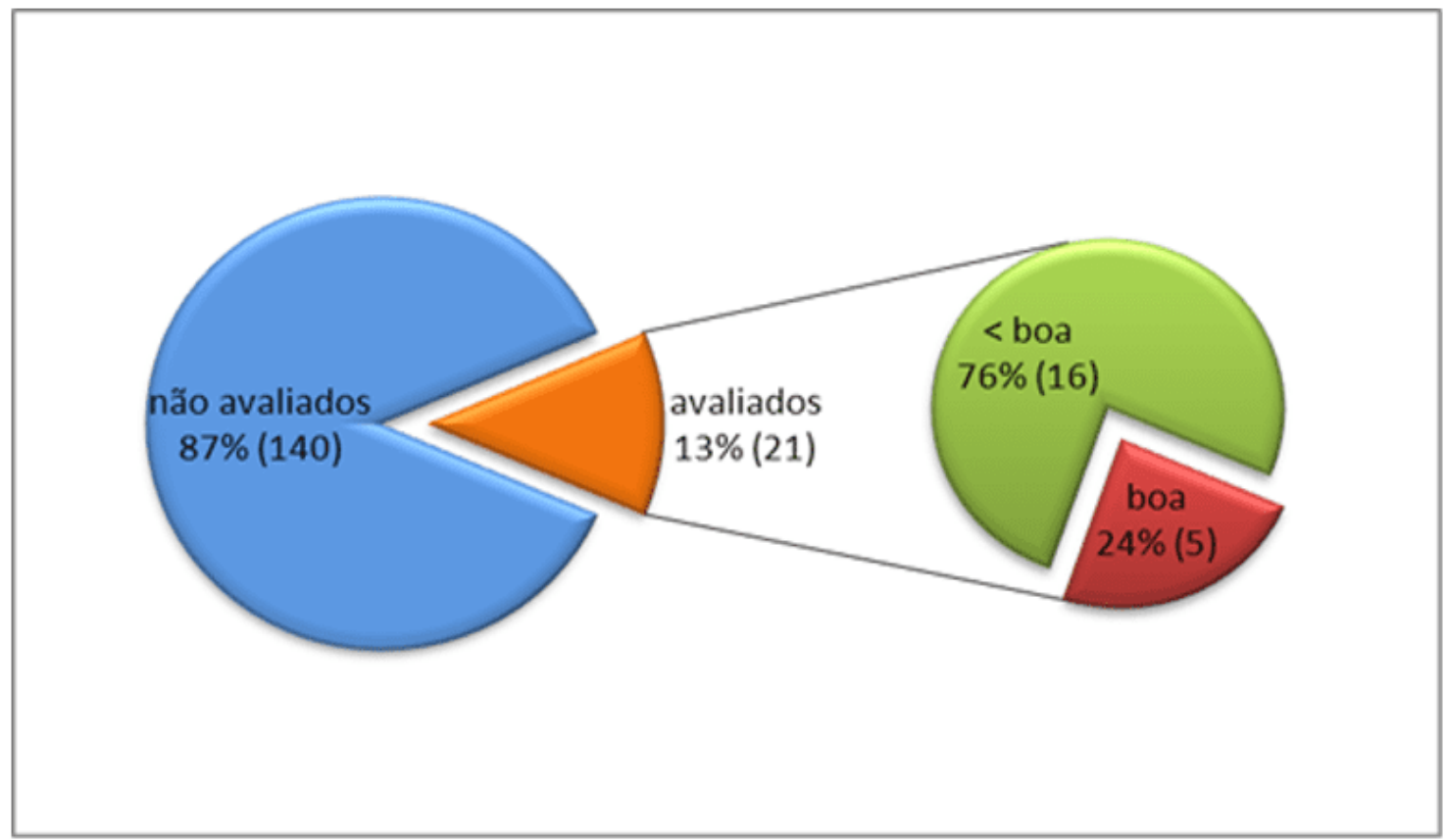

Source: Elaborated by the author

Table 3- Distribution of subjects according to AST, ALT and GGT results for hepatotoxicity evaluation in the pre, concomitant and post-ICC periods. SEAP HIV/AIDS, HC-FMUSP, São Paulo - 2008 to 2011

\begin{tabular}{|c|c|c|c|c|c|c|}
\hline \multirow[t]{3}{*}{ Exames } & \multirow[t]{3}{*}{ Período } & \multicolumn{4}{|c|}{ Sujeitos } & \multirow{2}{*}{$\frac{\text { Tota }}{*}$} \\
\hline & & $<$ & U/L & $\geq$ & U/L & \\
\hline & & $\mathrm{N}$ & $\%$ & $\mathrm{~N}$ & $\%$ & \\
\hline & Pre TPI & 142 & 88,2 & 19 & 11,8 & 161 \\
\hline \multirow[t]{5}{*}{ AST } & Concomitante ao TPI & 107 & 71,3 & 43 & 26,7 & 150 \\
\hline & Pós TPI & 130 & 86,1 & 21 & 13,9 & 151 \\
\hline & & $<$ & $\mathrm{U} / \mathrm{L}$ & $\geq$ & $U / L$ & ** \\
\hline & & $\mathrm{N}$ & $\%$ & $\mathrm{~N}$ & $\%$ & \\
\hline & Pre TPI & 136 & 85,0 & 24 & 15,0 & 160 \\
\hline \multirow[t]{5}{*}{ ALT } & Concom itante ao TPI & 107 & 71,3 & 43 & 28,7 & 150 \\
\hline & Pós TPI & 118 & 77,6 & 34 & 22,4 & 152 \\
\hline & & \multicolumn{2}{|c|}{$\leq 61 \mathrm{U} / \mathrm{L}$} & \multicolumn{2}{|c|}{$\geq 62 \mathrm{U} / \mathrm{L}$} & 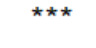 \\
\hline & & $\mathrm{N}$ & $\%$ & $\mathrm{~N}$ & $\%$ & \\
\hline & Pre TPI & 112 & 75,2 & 37 & 24,8 & 149 \\
\hline \multirow[t]{2}{*}{ GGT } & Concom itante ao TPI & 99 & 76,7 & 30 & 23,3 & 129 \\
\hline & Pós TPI & 95 & 74,8 & 32 & 25,2 & 127 \\
\hline
\end{tabular}

Source: Elaborated by the author 
Table 4- INH tablets prescribed, according to medical records and prescription, and the amount of tablets dispensed by the pharmacy, on average and median, per subject, during the ICC. SEAP HIV/AIDS, HC-FMUSP, São Paulo - 2008 to 2011

\begin{tabular}{cccccc}
\hline \multirow{2}{*}{ Variável } & \multicolumn{4}{c}{ Número de Comprimidos de Isoniazida } \\
\cline { 2 - 5 } & Média & Mediana & DP & Min - Max \\
\hline \multicolumn{2}{c}{ Cp. Prescritos } & & & & \\
& Prontuário & 573,2 & 550 & 162,94 & $12-1386$ \\
& Prescrição & 685,8 & 639 & 267,84 & $84-1837$ \\
Cp. Disp. & Farmácia & 504,9 & 530 & 150,18 & $90-850$ \\
\hline
\end{tabular}

Cp: comprimido; Disp: dispensado

146 sujeito s incluí dos

Source: Elaborated by the author

Table 5- Median ICC adhering, according to the INH dispensing rate, calculated based on medical records information and according to electronic prescription. SEAP HIV/AIDS, HC-FMUSP, São Paulo - 2008 to 2011

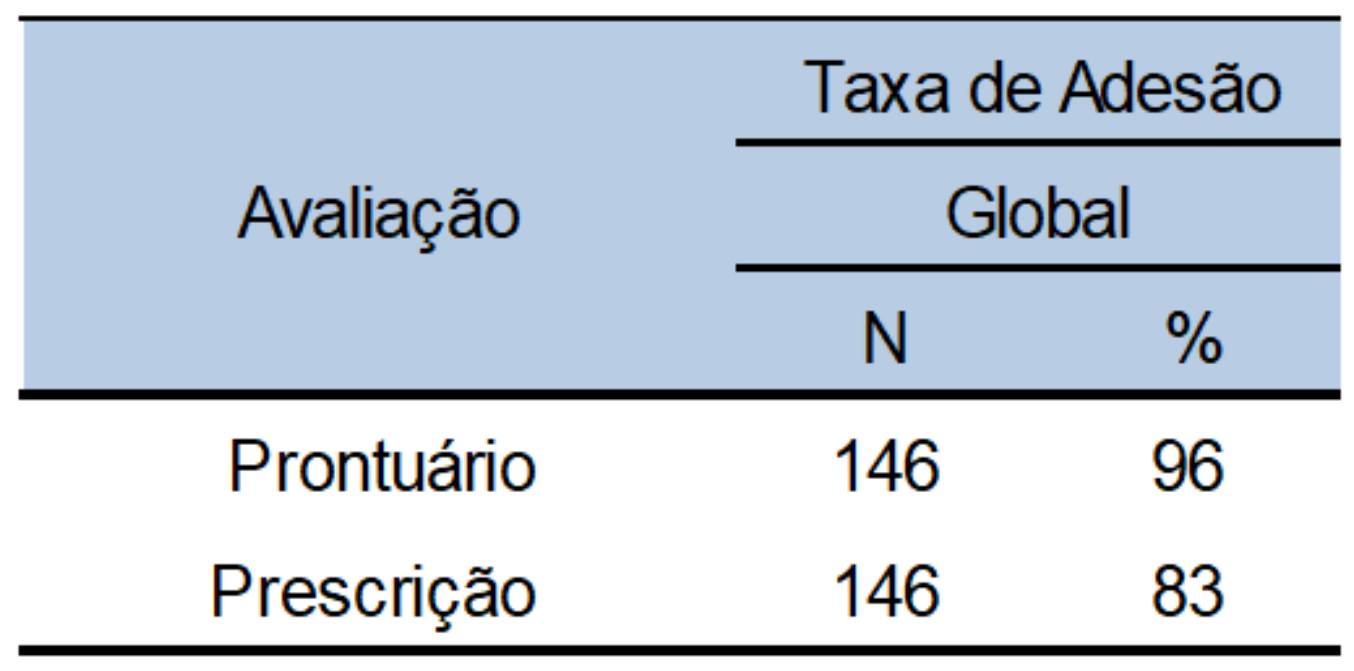

Source: Elaborated by the author 
Table 6- Rate of INH adhering to HIV/AIDS subjects according to variables of interest, SEAP HIV/AIDS, HC-FMUSP, São Paulo - 2008-2011

\begin{tabular}{|c|c|c|c|}
\hline Variáveis & $\mathbf{N}$ & \% adesão & $\mathbf{p}$ \\
\hline \multicolumn{4}{|l|}{ Sexo } \\
\hline M & 114 & 89,7 & 0,589 \\
\hline$F$ & 31 & 92,2 & \\
\hline \multicolumn{4}{|l|}{ Idace } \\
\hline$<50$ & 98 & 88,8 & 0,261 \\
\hline$\geq 50$ & 47 & 93,3 & \\
\hline \multicolumn{4}{|l|}{ Anos Inf. HIV } \\
\hline$\leq 4$ anos & 20 & 84,9 & 0,247 \\
\hline$\geq 5$ anos & 125 & 91,1 & \\
\hline \multicolumn{4}{|c|}{ Doença Concomitante } \\
\hline Sim & 112 & 91,6 & 0,174 \\
\hline Não & 33 & 85,6 & \\
\hline \multicolumn{4}{|c|}{ Uso de Drogas Lícitas/lícitas } \\
\hline Sim & 30 & 83,6 & 0,066 \\
\hline Não & 115 & 91,9 & \\
\hline \multicolumn{4}{|l|}{ Uso de TARV } \\
\hline Sim & 134 & 91,2 & 0,305 \\
\hline Não & 11 & 79,3 & \\
\hline \multicolumn{4}{|l|}{ Núm. de cp ARV/dia } \\
\hline$\leq 3 c p$ & 45 & 89,6 & 0,536 \\
\hline$\geq 4 \mathrm{cp}$ & 89 & 91,9 & \\
\hline \multicolumn{4}{|c|}{ Acompanhamento Médico } \\
\hline assistente & 123 & 90,7 & 0,602 \\
\hline residente & 22 & 88,0 & \\
\hline \multicolumn{4}{|c|}{1 . Avaliação médica do TPI } \\
\hline$\leq 30$ dias & 22 & 95,2 & 0,296 \\
\hline$\geq 31$ dias & 121 & 89,9 & \\
\hline \multicolumn{4}{|c|}{ CV pré TPI em TARV* } \\
\hline indetectável & 115 & 90,7 & 0,560 \\
\hline detectável & 19 & 93,7 & \\
\hline \multicolumn{4}{|c|}{ CV conc. TPI em TARV** } \\
\hline indetectável & 118 & 91,4 & 0,768 \\
\hline detectável & 8 & 93,6 & \\
\hline
\end{tabular}

Source: Elaborated by the author 


\section{DISCUSSION AND CONCLUSION}

In our study we did not identify factors associated with ICC membership. The specialized literature is controversial in relation to and this aspect: while, in some studies, similarly to ours, age, sex, time of infection, concomitant diseases, illicit drugs, TARV, medical follow-up, virological condition and ICC adhering (TULSKY et al, 2000; SHUKLA et al, 2002), were not associated with ICC membership, and others showed association with race/color, age, housing, alcohol, adverse event and country of origin (LOBUE et al, 2003; TULSKY et al, 2000; PARSYAN et al, 2007).

Of the 161 subjects, $12.4 \%$ (20) suffered complications during the ICC, these patients were excluded from the analysis of the ades, because such complications negatively influenced the continuity of patients to treatment. However, events such as hepatotoxicity were not reported in these complications. Regarding the risk of hepatotoxicity (elevation of liver function markers) assessed through laboratory test results, $12.4 \%$ of patients presented some type of complications, hepatotoxicity, adverse effect of well-defined and documented INH (CONDE et al, 2009; CHURCHYARD et al, 2007; COHN; O'BRIEN, 2000; $\mathrm{CONH}, 2000$ ), occurred in a discrete and transitory manner, and did not lead to suspension of the ICC. Apparently, the concern with adhering does not refer to all treatments homogeneously and in this study we identified that while $53 \%$ of the subjects had a record in the medical records of the assessment of TARV adhering only $13 \%$ had an assessment related to the ICC. Because it is a treatment to reduce the risk of TB and potentially hepatoxic, it would be desirable to be more concerned with its treatment (CONDE et al, 2009; COHN et al, 2000; COHN, 2000).

There are different methodologies for assessing the ICC's adto, ranging from the proportion of vials provided compared to the predicted, number of patients who finished treatment, proportion of dispensed tablets that were returned to the pharmacy, database with information on medication dispensing and self-report. (HIRANSUTHIKUL et al, 2005; WHO, 2008; TULSKY et al, 2000; SHUKLA et al, 2002; KABALI et al, 2011; BATKI et al, 2002; WHITE et al, 2003). 
In this study, the rate of ICC adhering through medical records and electronic prescription information was $96 \%$ and $83 \%$ respectively, both of which were higher than $80 \%$, which we initially considered appropriate for the ICC to be efficient (VEENING, 1968; FALLAB-STUBI et al, 1998; HIRANSUTHIKUL et al, 2005)

The high rate of ICC adhering can be attributed to service characteristics, reduced waiting time, extended opening hours, personal beliefs, the disease itself, among others (GUSMAO et al, 2006; WHO, 2003, REINERS et al, 2008; NEVES et al, 2010). This rate can be justified, at least partially, by practices adopted in medical and pharmaceutical care: between 2006 and 2008 the pharmacy service of SEAP HIV/AIDS began to schedule the dates of dispensing of medicines, unify the dispensations of different medications on the same date, inform the physicians, through notification in medical records, about the patient's no-show for removal of DRUGS from ART and INH, and, mainly, clarify patients, individually, about factors that increase the effectiveness of treatment, highlighting the importance of the intake of the medication according to the orientations received and its dispensing on the scheduled date. The pharmaceutical care performed adequately, with the objective of raising the quality of health and life of the patients, was ultimately the great responsible for the result achieved.

\section{FINAL CONSIDERATIONS}

Adhering to the recommended treatments is essential to achieve the expected result. Adession is a complex behavior, as well as its evaluation, in this study there are some limitations such as the absence of another method of evaluation of adhering, such as interviews with the medical professional or patient who could collaborate to identify difficulties in issues related to the number of individuals. However, even with the limitations it was possible to identify the membership of the ICC with active participation of the information provided by the Pharmacy Service. 


\section{REFERENCES}

AKOLO, Christopher et al. Treatment of latent tuberculosis infection in HIV infected persons. Cochrane database of systematic reviews, n. 1, 2010.

BATKI, Steven L. et al. A controlled trial of methadone treatment combined with directly observed isoniazid for tuberculosis prevention in injection drug users. Drug and alcohol dependence, v. 66, n. 3, p. 283-293, 2002.

BIGGAR, R. J. AIDS: a global problem. Cancer detection and prevention, v. 12, n. 1-6, p. 169-174, 1988.

BLANC, François-Xavier et al. Treatment strategies for HIV-infected patients with tuberculosis: ongoing and planned clinical trials. The Journal of infectious diseases, v. 196, n. Supplement_1, p. S46-S51, 2007.

BRASIL. Ministério da Saúde. Secretaria de Vigilância em Saúde. Boletim Epidemiológico Tuberculose. Brasília (DF): Ministério da Saúde; 2020. Disponível em: < http://www.aids.gov.br/pt-br/pub/2020/boletim-epidemiologicode-turbeculose-2020>. Acesso em 28 de fev. de 2021.

BRASIL. Ministério da Saúde. Secretaria de Vigilância em Saúde. Departamento de DST, Aids e Hepatite Virais. Boletim Epidemilógico Especial- Aids 2020. Brasília (DF): Ministério da Saúde; 2020. Disponível em: < http://www.aids.gov.br/pt-br/pub/2020/boletim-epidemiologico-hivaids-2020>. Acesso em 28 de fev. de 2021.

CHURCHYARD, Gavin J. et al. Tuberculosis preventive therapy in the era of HIV infection: overview and research priorities. The Journal of infectious diseases, v. 196, n. Supplement_1, p. S52-S62, 2007.

COHN, David L. et al. Targeted tuberculin testing and treatment of latent tuberculosis infection. MMWR Morb Mortal Wkly Rep, v. 49, n. 6, p. 1-54, 2000.

COHN, David L. Treatment of latent tuberculosis infection: renewed opportunity for tuberculosis control. Clinical infectious diseases, v. 31, n. 1, p. 120-124, 2000. 
CONDE, Marcus Barreto et al. III Diretrizes para tuberculose da Sociedade Brasileira de Pneumologia e Tisiologia. Jornal Brasileiro de Pneumologia, v. 35, n. 10, p. 1018-1048, 2009.

DE COCK, Kevin M.; JAFFE, Harold W.; CURRAN, James W. Reflections on 30 years of AIDS. Emerging infectious diseases, v. 17, n. 6, p. 1044, 2011.

DE GUSMÃO, Josiane Lima; MION JR, Décio. Adesão ao tratamentoconceitos. Rev Bras Hipertens vol, v. 13, n. 1, p. 23-25, 2006.

DUARTE, Raquel et al. Tratamento da tuberculose latente: Revisão das normas, 2006. Revista Portuguesa de Pneumologia (English Edition), v. 13, n. 3, p. 397-418, 2007.

EL-SADR, Wafaa Mahmoud; TSIOURIS, Simon. HIV-associated tuberculosis: diagnostic and treatment challenges. 2008.

ESTATISTICAS. UNAIDS. Disponível em: https://unaids.org.br/estatisticas/>. Acesso em 25 de fev. de 2021.

FALLAB-STUBI, C. L. et al. Electronic monitoring of adherence to treatment in the preventive chemotherapy of tuberculosis. The International Journal of Tuberculosis and Lung Disease, v. 2, n. 7, p. 525-530, 1998.

FÄTKENHEUER, Gerd et al. The return of tuberculosis. Diagnostic microbiology and infectious disease, v. 34, n. 2, p. 139-146, 1999.

GORENOI, Vitali; SCHÖNERMARK, Matthias P.; HAGEN, Anja. Interventions for enhancing medication compliance/adherence with benefits in treatment outcomes. GMS health technology assessment, v. 3, 2007.

HIRANSUTHIKUL, N. et al. INH preventive therapy among adult HIV-infected patients in Thailand. The International Journal of Tuberculosis and Lung Disease, v. 9, n. 3, p. 270-275, 2005. 
HORSBURGH JR, C. Robert; RUBIN, Eric J. Latent tuberculosis infection in the United States. New England Journal of Medicine, v. 364, n. 15, p. 1441-1448, 2011

KABALI, C. et al. Completion of isoniazid preventive therapy and survival in HIVinfected, TST-positive adults in Tanzania. The International journal of tuberculosis and lung disease, v. 15, n. 11, p. 1515-1522, 2011.

LEUNG, Chi Chiu et al. Treatment of latent infection with Mycobacterium tuberculosis: update 2010. European Respiratory Journal, v. 37, n. 3, p. 690711, 2011.

LOBUE, Philip A.; MOSER, Kathleen S. Use of isoniazid for latent tuberculosis infection in a public health clinic. American journal of respiratory and critical care medicine, v. 168, n. 4, p. 443-447, 2003.

NEVES, Lis Aparecida de Souza; REIS, Renata Karina; GIR, Elucir. Adesão ao tratamento por indivíduos com a coinfecção HIV/tuberculose: revisão integrativa da literatura. Revista da Escola de Enfermagem da USP, v. 44, n. 4, p. 11351141, 2010.

OIGMAN, Wille. Métodos de avaliação da adesão ao tratamento antihipertensivo. Rev Bras Hipertens, v. 13, n. 1, p. 30-4, 2006.

PADMAPRIYADARSINI, C.; NARENDRAN, G.; SWAMINATHAN, Soumya. Diagnosis \& treatment of tuberculosis in HIV co-infected patients. The Indian journal of medical research, v. 134, n. 6, p. 850, 2011.

PARSYAN, Armen E. et al. Predictors of failure to complete treatment for latent tuberculosis infection. Journal of infection, v. 54, n. 3, p. 262-266, 2007.

REINERS, Annelita Almeida Oliveira et al. Produção bibliográfica sobre adesão/não-adesão de pessoas ao tratamento de saúde. Ciência \& Saúde Coletiva, v. 13, p. 2299-2306, 2008. 
SHUKLA, Sunita J. et al. Factors associated with the treatment of latent tuberculosis infection among health-care workers at a midwestern teaching hospital. Chest, v. 122, n. 5, p. 1609-1614, 2002.

STERLING, Timothy R.; PHAM, Paul A.; CHAISSON, Richard E. HIV InfectionRelated tuberculosis: Clinical manifestations and treatment. Clinical Infectious Diseases, v. 50, n. Supplement_3, p. S223-S230, 2010.

TULSKY, Jacqueline Peterson et al. Adherence to isoniazid prophylaxis in the homeless: a randomized controlled trial. Archives of internal medicine, v. 160, n. 5 , p. 697-702, 2000.

VAN MIL, JW Foppe; SCHULZ, Martin. A review of pharmaceutical care in community pharmacy in Europe. Harvard Health Policy Review, v. 7, n. 1, p. 155-168, 2006.

VEENING, G. J. Long term isoniazid prophylaxis. Controlled trial on INH prophylaxis after recent tuberculin conversion in young adults. Bulletin of the International Union against Tuberculosis, v. 41, p. 169-171, 1968.

VERONESI R. Tratado de Infectologia. 3모 ed. São Paulo: Atheneu; 2005. p.1139-206

WHITE M, C. et al. Effect of directly observed preventive therapy for latent tuberculosis infection in San Francisco. The International Journal of Tuberculosis and Lung Disease, v. 7, n. 1, p. 30-35, 2003.

WORLD HEALTH ORGANIZATION et al. Adherence to long-term therapies: evidence for action. World Health Organization, 2003.

WORLD HEALTH ORGANIZATION et al. Operations manual for delivery of HIV prevention, care and treatment at primary health centres in high-prevalence, resource-constrained settings: Edition 1 for fieldtesting and country adaptation. 2008. 
[1] Clinical Pharmacist in Infectious Diseases. Master of Medical Sciences. Multiprofessional Oncology Specialist. Specialist in Educational Planning and Teaching of Higher Education. Specialist in Hospital Pharmacy.

${ }^{[2]}$ Infectious Doctor. PhD in Pathology.

Submitted: March, 2021.

Approved: April, 2021. 